\section{Future of Law and Development Research: An Introduction to the Encyclopedia of Law and Development}

When the General Editors started discussing this introduction, our first idea was to attempt a history of law and development. We decided against it - not only because the entries in this Encyclopedia provide ample historical material - but primarily because there are not one, but many histories of law and development. These histories are located, and inevitably informed by particular understandings of the relationship between law and development.

In developed countries, law and development historically referred to development cooperation aimed at legal reform in developing countries. In a post-colonial context, it implied continued involvement by the former colonial powers in the design of the legal systems of the newly independent States. In a Cold War context, it meant ensuring that the legal systems in developing countries reflected the economic and political zone of influence of which they were (made) a part. As a result, the US history of law and development differs significantly from the Soviet or European histories of the same.

At the receiving end of development aid for legal reform were developing countries attempting to mobilize law to both reflect and direct their own societies. In this context, the terminology of 'law and development' was used less frequently; the emphasis was on how law could be used to foster economic growth, tackle poverty, deal with inequality and the like.

In our own research, perhaps coincidentally, the General Editors have been mostly engaged with yet another dimension of 'law and development', i.e. the role of global institutions. Here, the perspective is different again: the emphasis is not on bilateral relationships between donor and recipient countries, or on legal reform in the Global South, but on how international law and international organizations impact - for better or for worse - on development within and among countries. Law and development scholarship tends to focus on the (dis)connect between development objectives promoted through global legal and institutional reform projects and the results they achieve on the ground in developing countries.

It is striking to note how many of the terms used to describe 'law and development' historically - and in the preceding paragraphs - have now become contested not only among States, but also among law and development scholars. The language of development cooperation between donor and recipient countries is now largely avoided in policy circles; it has been replaced by talk about global partnerships and global engagement. Development has become 'sustainable' development and, as a concept, is meant to apply equally to both developed and developing countries. The term 'development' itself is rejected by some, as it suggests a process of transformation imposed by one actor on another deemed less developed. The usefulness of categorizing countries as 'developed' or 'developing' is increasingly questioned, as modalities of differentiation between countries multiply. On the other hand, it is argued that maintaining the term 'developing countries' remains politically relevant, in order to maintain a sense of unity between countries that shared an experience of colonial domination. The North is in the South and vice versa; the Global South can now also refer to underprivileged neighbourhoods in the geographical North. The Third World was invented when there was an East and a West. The concept of law (in development) has opened up to informal, customary and private forms of regulation.

The terminological shifts demonstrate an unease within current scholarship about the past: about how law and lawyers facilitated colonialism, imposed conditionalities reflecting the preferences of hegemonic countries and global institutions, authoritarianism and acculturation. The legitimacy of law and development as an ongoing scholarly venture thus hinges on avoiding the replication of injurious past practices.

It is clear, however, that today, law and development research remains plural, both in terms of how the functioning of law with regard to development is envisaged; the areas and levels of regulation that are prioritized, and in how it views the extent to which scholarship should direct policy and law reform. The entries in the Encyclopedia reflect this variety. Our authors, for instance, do not necessarily agree on the 
suitability and or feasibility of the Sustainable Development Goals. As Editors, we have not sought to address contradictory positions, nor do we necessarily agree with all positions taken in the book. These contradictions are part and parcel of the field. Having said this, law and development scholars are well advised to consciously situate themselves within the field. The personal identity and experience of the writer is not disconnected from the history of law and development, and it is certainly useful to reflect on what that position means for one's own work and the dialogue with others that are differently situated.

In crafting the Encyclopedia, we have sought to build on insights from discussions that have taken place over the last few years within the law and development research community. They may be summarized as follows:

Law and development research stands in need of a dialogue between law and other disciplines, given that development is not primarily a legal concept. In this area of scholarship, inevitably the social functioning of the law, and its impact on development objectives, come to the fore. Engagement with research from other disciplines, even if it is methodologically complex and may require a team of researchers, is therefore to be welcomed. Given the particular concern within development studies with those among and within societies facing inequalities, transdisciplinarity, inspired by the experiences of those most affected by inequality, is also to be encouraged. Transdisciplinarity requires researchers to take responsibility for ensuring that the products of their research benefit those who have contributed to it.

The law in law and development is not limited to a specific area of the law. Most legal researchers, including those contributing to this volume, have an expertise in a specific area of the law or focus on a particular level of regulation. The areas covered in law and development research are vast: economic law, environmental law, labour law, administrative law, private law, human rights.... Law and development scholars may self-identify as international, regional or domestic lawyers, comparatists, legal anthropologists, legal theorists and so on. What a legal approach to development as a minimum requires, however, is an identification and acknowledgment of all legal norms that are relevant to the development issue under review. The legal norms are as interconnected as the different dimensions of development.
Consequently, it makes sense that even if the emphasis of the researcher is on a particular area or level of the law, the plurality of applicable norms at other levels of regulation or in other areas of the law, and their interplay should be taken into account.

Knowledge from the Global South is insufficiently accessible and valued within current law and development research. The obstacles are well documented: researchers based in the Global South have little access to local funds for research (including field work); they often work in environments where research is not prioritized; and they face the prohibitive cost of accessing internationally published material. When quality research in law and development, or more broadly in the social sciences, does get generated, it is not necessarily produced in English. If no financial resources are available for translation, valuable, original work may never reach the global audience it deserves. Many a manuscript based on data generated in the South by Southern researchers has been rejected because funding for language review is absent. In practice, research produced at institutions in the North but based on data gathered locally in the South may stand a better chance of international publication, resulting in a particular brand of extractivism. In addition, publishers tend to cater for the interests of affluent markets where they can sell. The production and publication of knowledge replicates global inequality. The challenge then is how to ensure a truly equal bi-directional flow of knowledge between scholars located in the Global South and the Global North.

Finally, given the ambivalent role law has played over the years in development relationships between North and South and in dealing with domestic inequality, law and development research should be critical of the law, i.e. reflect on to what extent the law under review supports power dynamics that maintain established privileges, and is able to achieve its stated objectives.

The Encyclopedia emerged from the Editors' collaboration in the context of the Law and Development Research Network (LDRn). This Network was established in 2017 in order 'to enhance knowledge and understanding of the role of law, both domestic and international, in relation to development and governance, as perceived globally and locally' and 'to engage in fruitful discussions from both orthodox and critical perspectives on the role of law in 
development'. The idea of an Encyclopedia intended as a reference book for those interested in acquainting themselves with this area of research originated from discussions at the LDRn annual conference in 2017 and 2018 and steering committee meetings. Our publisher, Edward Elgar, attended activities organized by the Network from the start, and expressed a keen interest in publishing research produced within its fold.

The Associate Editors are all affiliated with LDRn institutions. Each of them contributed to a specific sub-theme on: Actors (Philipp Dann, Humboldt University of Berlin), Economic Law (Celine Tan, University of Warwick), Governance and Human Rights (Elina Pirjatanniemi, Åbo Akademi University) and the Sustainable Development Goals (Avinash Govindjee, Nelson Mandela University). In addition, the General Editors took responsibility for the 'Environmental Law' and 'Concepts' sub-themes.

The Associate Editors contributed to identifying the entries for their respective sub-theme, and contacted potential authors. During the drafting process, the sub-themes served as a vehicle for the division of labour. They have disappeared from the final book, where entries are simply listed in alphabetical order. All entries, including this introduction, are limited to approximately 2,000 words and ten references, which allows authors to interpret the essential debates in relation to a topic from their perspective. Any choice of entries will always be subject to debate. We attempted to strike a balance between issues that were topical at the time of publication and others that are more foundational, and perhaps also perennial. The Editors were supported at the Law and Development Research Group of the University of Antwerp by $\mathrm{PhD}$ researcher Alberto Pecoraro, who maintained communication with all authors throughout the complex drafting and double peer review process.
The majority of the authors contributing to the Encyclopedia are from the Global South. About one-third of the authors are based at institutions in the Global South. Some are early career researchers; others, senior authorities in the field.

The Encyclopedia is therefore not a Handbook of authoritative scholarly essays comprehensively dealing with the issue at hand, but it does show a variety of voices writing from very different perspectives, differing sensitivities and in different styles. It offers a picture of the diversity of the field today and perhaps, also of the direction into which it is bound to evolve. For these reasons, the General Editors hope the book may also be useful for supporting law and development curricula, regardless of where they are located.

We acknowledge that the accessibility of the Encyclopedia remains limited for researchers based in the Global South. The publisher offers the Encyclopedia material in the schemes run by EIFL and GOALII, which give free of charge or low-cost access to institutions in the Global South. We were, however, unable to simultaneously establish an Open Access Repository on request.

In conclusion, our sense is that reports on the death of law and development as a field of inquiry were greatly exaggerated. The field has a future, but it also has a past. In our view, law and development has a future if it is understood as an equal exchange of knowledge between scholars in the Global South and the Global North on how law impacts on societies in the Global South, as well as on marginalized and underprivileged communities in the North. This can be done, but it requires scholarly self-awareness rather than estrangement, and a conscious self-critical effort. We hope the Encyclopedia can make a contribution in this regard.

Koen de Feyter, Gamze Erdem Türkelli AND STÉPHANIE DE MoERLOOSE 